УДК 159.34 .01

DOI 22185186.2019.1.02

Богдан Шуневич

\title{
ПЕРСПЕКТИВНИЙ НАПРЯМ НАУКОВОЇ РОБОТИ МАГІСТРІВ-ПСИХОЛОГІВ
}

Підсумком знань, умінь і навичок з основних дисциплін, вивчених упродовж навчання у магістратурі закладу вищої освіти, є дипломна робота - самостійне наукове дослідження, на підставі захисту якого екзаменаційна комісія присвоює курсанту чи студенту кваліфікацію магістра. Важливою передумовою для написання магістерської роботи є перші наукові дослідження курсантів і студентів у формі курсових робіт на другому-третьому курсах і бакалаврської роботи на четвертому курсі.

Провідними напрямами магістерських робіт курсантів, студентів денної та слухачів заочної форм навчання кафедри практичної психології та педагогіки Львівського державного університету безпеки життєдіяльності (ЛДУ БЖД) за спеціальністю 053 «Психологія» є «психодіагностика психічних процесів та основних психологічних властивостей працівника пожежно-рятувальної служби та їхнього впливу на професійну діяльність; психокорекція порушень емоційно-вольової сфери особистості при виконанні професійних завдань; психолого-педагогічна підготовка працівників пожежно-рятувальної служби» [1, с. 4], наприклад, «Взаємозв’язок розвитку стресостійкості та агресивності майбутніх рятувальників», «Психологічні особливості формування професійної Я-концепції майбутніх рятувальників», «Удосконалення психологічної підготовки працівників служби порятунку до роботи в умовах надзвичайних ситуацій» та ін.

Викладачі кафедри практичної психології та педагогіки часто практикують нарощування складності виконання досліджень кожного курсанта/студента в рамках якоїсь однієї окремої тематики спочатку в формі курсових робіт, потім - бакалаврської, а пізніше - магістерської роботи, наприклад, курсова робота одного зі студентів нашої кафедри стосувалася провідного мотиву до занять у спортсменів, а з часом переросла в тему магістерської роботи «Особистісні фактори мотивації до фізичної культури в учнів старших класів».

Ще одним напрямом підготовки та захисту магістерських робіт на кафедрі практичної психології та педагогіки є дослідження психологічних і педагогічних особливостей організації дистанційного і комбінованого

(C) Богдан Шуневич, 2019 
навчання в освітніх закладах України [6], особливо курсантів ЛДУ БЖД, які часто поєднують навчання та роботу в екстремальних умовах під час постійних короткострокових і довгострокових виїздів на пожежі та інші надзвичайні ситуації впродовж усього періоду навчання в університеті.

Мета статті - описати причини виникнення, коротку історію, стан i перспективи нового напряму підготовки та захисту магістерських робіт курсантами і студентами кафедри практичної психології та педагогіки ЛДУ БЖД з урахуванням вітчизняного досвіду в цій сфері.

Початком організації таких досліджень стало проведення теоретичних і практичних занять із дисципліни «Теорія і практика дистанційного навчання» для магістрів першого року навчання кафедри практичної психології та педагогіки. Під час лекційних занять курсанти і студенти вивчають основні напрями досліджень із теорії дистанційного навчання в Україні та за кордоном; історію розвитку кореспондентського, відкритого дистанційного електронного та комбінованого навчання; основні терміни 3 цієї тематики та їх визначення; підходи до класифікації моделей організації дистанційного і комбінованого навчання, їхніх поколінь і періодів розвитку, основні складові частин організації дистанційного та комбінованого навчання в Україні зокрема та тенденції їхнього розвитку в Європі і в Північній Америці загалом, аспекти економіки і маркетингу нової форми навчання, а на практичних заняттях створюють дистанційні курси (ДК) з різних дисциплін за допомогою віртуального навчального середовища Moodle на базі Віртуального університету ЛДУ БЖД.

Більшість ДК із дисциплін, які читають викладачі кафедри практичної психології та педагогіки, вже укладено [2], тому останнім часом курсанти і студенти в основному беруть участь в оновленні цих курсів та приступили до дослідження психолого-педагогічних особливостей організації дистанційного і комбінованого навчання, а також особливостей укладання дистанційних курсів із психологічних дисциплін у закладах вищої освіти (ЗВО) України, зокрема в ЛДУ БЖД. Наприклад, «протягом першого семестру 2015-2016 н. р. курсанти та студенти магістерського рівня спеціальності «Практична психологія» створили для кафедр Навчальнонаукового інституту психології та соціального захисту 24 ДК, які викладачі використовують поки що як допоміжні навчальні матеріали, а в перспективі - для дистанційного навчання. Серед цих дистанційних курсів шість було укладено для психологічних дисциплін, а саме: «Основи психотерапії»; «Основи психокорекції»; «Юридична психологія»; «Міжособистісне спілкування»; «Психологія здоров'я»; «Психологія та педагогіка вищої школи» [7]. У січні 2018 р. із загальної кількості 84 дисциплін 
викладачами, курсантами і студентами було укладено 77 дистанційних курсів. Банк дисциплін на кафедрі практичної психології та педагогіки постійно поповнюється новими дисциплінами, наприклад, у згаданий вище період з'явилося 16 нових дисциплін, а отже, викладачам доводиться постійно укладати або оновлювати ДК [4; 5].

Починаючи 3 першого курсу, курсанти і студенти використовують матеріали дистанційних курсів у процесі денного і заочного навчання. Тобто вони мають можливість проводити подібні дослідження стосовно психолого-педагогічних особливостей організації дистанційного і комбінованого навчання на основі дистанційних курсів, із якими вони працювали, навчаючись на першому-четвертому курсах, також для написання курсових, бакалаврської та магістерської робіт.

Визначення психолого-педагогічних засад дистанційного навчання $\epsilon$ обов'язковою передумовою його застосування в освітньому процесі. Розроблення психологічних засад дистанційного навчання сприятиме вирішенню його провідного соціального завдання для забезпечення можливостей здобуття освіти будь-якого рівня і якості та створенню умов для постійного саморозвитку кожної людини незалежно від іiі індивідуально-психологічних особливостей, формуванню психологічної готовності до дистанційного навчання як необхідної умови його ефективності.

В Україні цими питаннями займаються співробітники Лабораторії нових інформаційних технологій навчання Інституту психології імені Г. Костюка НАПН України й інші установи. Опубліковано ряд праць із цієї тематики. Наприклад, у монографії «Дистанційне навчання: психологічні засади» [3] розглянуто теоретико-методологічні засади проектування дистанційних навчальних середовищ, проведений психологічний аналіз навчальної технології та психологічних механізмів дистанційного навчання, проаналізовані критерії ефективності та принципи контролю у дистанційних курсах; проведено психологічний аналіз парадигматичних змін у структурі навчання в дистанційному форматі, обгрунтовано психологічні засади проектування дистанційного навчання як середовища саморозвитку, розглянуто інтелектуальний розвиток як мету і засіб дистанційного навчання; згаданий вище теоретичний підхід проілюстровано експериментальними дослідженнями в дистанційних середовищах, присвяченими формуванню психологічної готовності до дистанційного навчання й аналізу інтернет-тренінгів як чинника особистісних змін користувачів сайтів; проаналізовано розвиток психологічних компетенцій дорослих засобами дистанційного навчання, психолого-педагогічні принципи навчання дорослих; описано принципи проектування дистанційно- 
го курсу, а також результати дослідження критеріїв психологічної комфортності дистанційного навчання, проектування та програмування моделі учня як складової навчального контенту системи та психологічної моделі комп’ютерно- й інтернет-залежної особи.

Ми маємо досвід організації подібних досліджень на стику прикладної лінгвістики і дистанційного навчання у Національному університеті «Львівська політехніка» (НУЛП) під час підготовки та захисту магістерських робіт студентами кафедри прикладної лінгвістики у 20052007 рр. Студентам кафедри прикладної лінгвістики також читався курс лекцій «Теорія і практика дистанційного навчання», проводилися практичні заняття, під час яких вони укладали дистанційні курси 3 англійської мови для курсантів і студентів Львівського державного університету безпеки життєдіяльності, досліджували, наприклад, програмне забезпечення для створення відеоматеріалів, створювали їх самостійно або 3 участю офіцерів, курсантів, спеціалістів Лабораторії дистанційного навчання ЛДУ БЖД, використовували їх у дистанційному курсі, бачили результати своєї роботи під час занять із курсантами і студентами, захищали магістерські роботи в Лабораторії дистанційного навчання ЛДУ БЖД в присутності Державної екзаменаційної комісії НУЛП, офіцерів і викладачів кафедри іноземних мов і технічного перекладу ЛДУ БЖД (див. Фото 1), а також у відеорежимі за участю викладачів мовної підготовки Національного університету цивільного захисту України, викладачів львівських і київських вищих закладів освіти і своїх батьків.

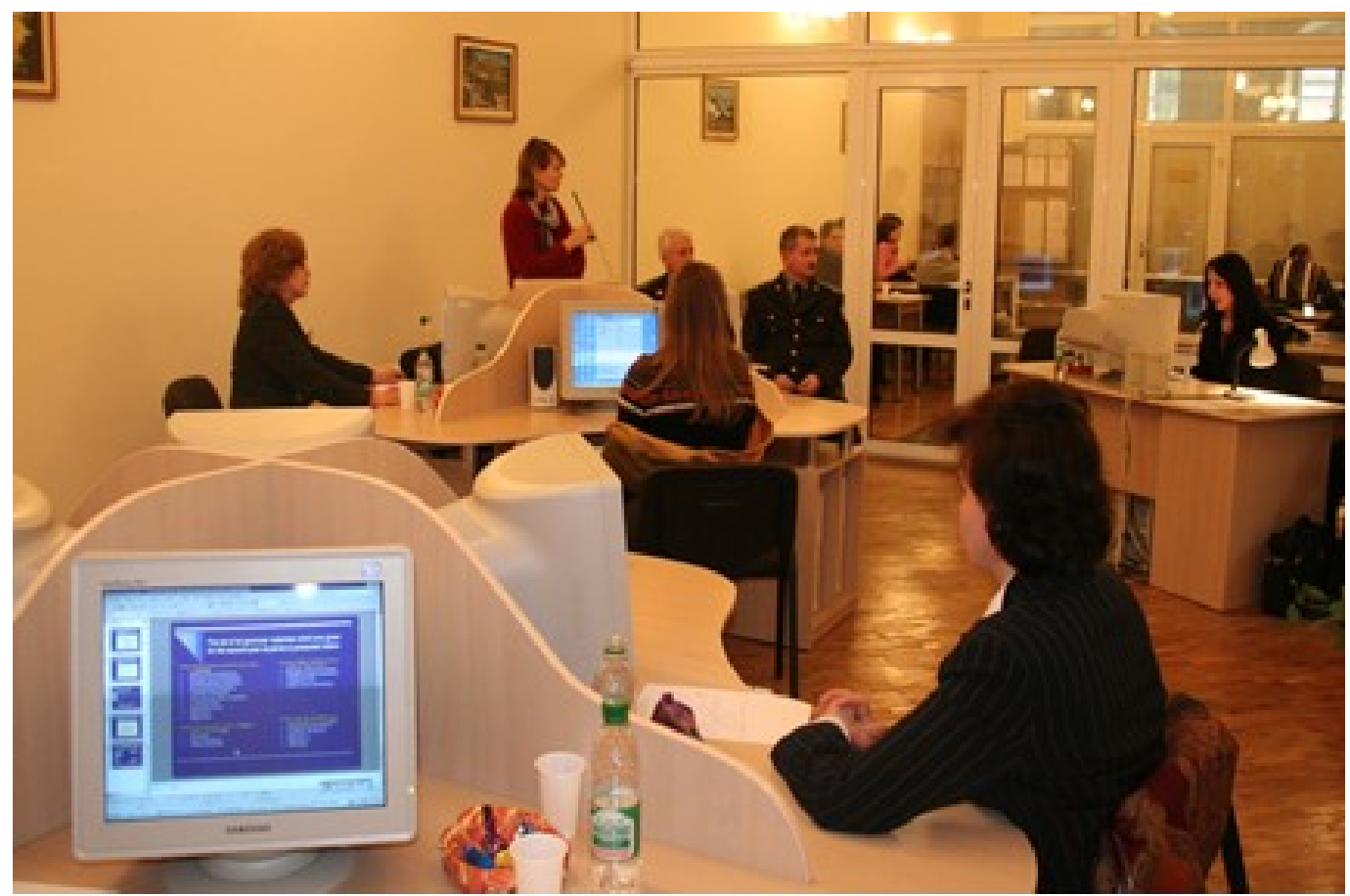




\section{Фото 1 - Захист магістерських робіт студентами прикладної лінгвістики НУЛП в ЛДУ БЖД у грудні 2006 р.}

Таким чином, проведені курсантами і студентами попередні дослідження психолого-педагогічних особливостей впровадження дистанційного і комбінованого навчання показали їх перспективність, а найкращі з цих досліджень будуть захищені у вигляді магістерських робіт.

\section{Лimepamypa:}

1. Виконання дипломних робіт зі спеціальності 053 «Психологія (практична психологія)» : метод. реком. / Укл. А. Литвин, Р. Сірко; Львівський державний університет безпеки життєдіяльності ДСНС України. Львів : ЛДУБЖД, 2018. 44 с.

2. Віртуальний університет. URL: http://ubgd.lviv.ua/moodle

3. Дистанційне навчання: психологічні засади : монографія / М. Смульсон, Ю. Машбиць, М. Жалдак та ін. ; за ред. М. Смульсон. Кіровоград : Імекс-ЛТД, 2012. 240 с.

4. Шуневич Б. Використання інноваційних технологій у процесі підготовки майбутніх психологів. Життєдіяльність та життетворчість особистості в особливих умовах : монографія. Упорядн. : О. Кривопишина, Н. Терентьєва ; за наук. ред. М. Козяра. Львів, 2018. С. 397-417.

5. Шуневич Б. Дистанційні курси з гуманітарних дисциплін для підготовки фахівців у сфері цивільного захисту. Сучасний стан циивільного захисту України та перспективи розвитку : Матеріали XX Всеукраїнської науково-практичної конференції, м. Київ, 9-10 жовтня 2018 р. К. : Видавничий дім «Гельветика», 2018. С. 512-515.

6. Шуневич Б. Новий напрям магістерських досліджень для спеціальності «Психологія (практична психологія)». Освітньо-наукове забезпечення діяльності складових сектору безпеки і оборони Украӥни : тези ХІ Всеукраїнської науково-практичної конференції (Хмельницький, 15 листопада 2018 р.). Хмельницький : Вид-во НАДПСУ, 2018. С. 672-673.

7. Шуневич Б. Перспективи запровадження дистанційного навчання у Навчально-науковому інституті психології та соціального захисту. Віртуальний освітній простір: психологічні проблеми : тези IV Міжнародної науковопрактичної інтернет-конференції, 12 квітня - 31 травня 2016 p. URL: http://www.newlearning.org.ua/content/tezy-iv-mizhnarodnoyi-naukovopraktychnoyi-internet-konferenciyi-virtualnyy-osvitniy-prostir

\section{References (transliterated and translated):}

1. Vykonannia dyplomnykh robit zi spetsialnosti 053 «Psykholohiia (praktychna psykholohiia)» : metod. rekom. (Completion of diploma papers on the Psychology (Practical psychology) 053 speciality : methodical recommendations). Compiled by A. Lytvyn, R. Sirko; Lviv State University of Life Safety at SES of Ukraine. Lviv : LSU LS, 2018. 44 p. (in Ukrainian).

2. Virtualnyi universytet (Virtual University). URL : http://ubgd.lviv.ua/moodle. (in Ukrainian).

3. Dystantsiine navchannia: psykholohichni zasady : monohrafiia (Distance learning: psycological footing : monograph) / M. Smulson, Yu. Mashbits, M. Zhaldak et. al. ; ed. by M. Smulson. Kirovohrad : Imeks-LTD, 2012. 240 p. (in Ukrainian). 
4. Shunevych B. Vykorystannia innovatsiinykh tekhnolohii u protsesi pidhotovky maibutnikh psykholohiv (Usage of innovative technologies in the process of future psychologist training). Zhyttiediialnist ta zhyttietvorchist osobystosti $v$ osoblyvykh umovakh : monohrafiia (Life safety and life creative work of personality in special conditions : monograph) /Compilers: O. Kryvopyshyna, N. Terentyeva ; edited by M. Kozyar. Lviv, 2018. P. 397-417. (in Ukrainian).

5. Shunevych B. Dystantsiini kursy z humanitarnykh dystsyplin dlia pidhotovky fakhivtsiv u sferi tsyvilnoho zakhystu (Distance courses on humanitarian subjects for training specialists in the sphere of civil protection). Suchasnyi stan tsyvilnoho zakhystu Ukrainy ta perspektyvy rozvytku (Modern state of Ukrainian civil protection and prospects of development : Proceedings of the 20th Ukrainian scientific and practical conference, Kyiv city, October 9-10, 2018). Kyiv : Helvetyka Publishing House, 2018. P. 512-515. (in Ukrainian).

6. Shunevych B. Novyi napriam mahisterskykh doslidzhen dlia spetsialnosti «Psykholohiia (praktychna psykholohiia)» (A new trend of master's degree researches for Psychology (Practical Psychology) speciality) // Osvitno-naukove zabezpechennia diialnosti skladovykh sektoru bezpeky i oborony Ukrainy : tezy KhI Vseukrainskoi naukovo-praktychnoi konferentsii (Educational and scientific provision of the activity of the Ukrainian safety and defence sector components : Abstracts of the 11th Ukrainian scientific and practical conference) (Khmelnytskyi city, November 15, 2018). Khmelnytskyi : NASBGSU Publishing House, 2018. P. 672-673. (in Ukrainian).

7. Shunevych B. Perspektyvy zaprovadzhennia dystantsiinoho navchannia u Navchalno-naukovomu instytuti psykholohii ta sotsialnoho zakhystu (Prospects of distance learning implementing at Educational and research institute of psychology and social protection). Virtualnyi osvitnii prostir: psykholohichni problemy : tezy IV Mizhnarodnoi naukovo-praktychnoi internet-konferentsii, 12 kvitnia - 31 travnia 2016 r.(Virtual educational space: psychological issues : Abstracts of the 4th International scientific and practical Internet-conference, April 12 - May 31, 2016). URL : http://www.newlearning.org.ua/content/tezy-iv-mizhnarodnoyi-naukovopraktychnoyi-internet-konferenciyi-virtualnyy-osvitniy-prostir (in Ukrainian).

Стаття надійшла до редакції 07.12.2018

Б. Шуневич

\section{Перспективний напрям наукової роботи магістрів-психологів}

У статті проведено аналіз теперішніх напрямів дослідження курсантів і студентів у формі курсових, бакалаврських і магістерських робіт кафедри практичної психології та педагогіки Львівського державного університету безпеки життєдіяльності, обгрунтовано необхідність, стан і перспективи нового напряму підготовки та захисту магістерських робіт на основі досліджень психологічних і педагогічних особливостей укладання дистанційних курсів, організації дистанційного і комбінованого навчання в закладах вищої освіти України з урахуванням вітчизняного досвіду у цій сфері, і особливо навчання курсантів ЛДУ БЖД, які часто по- 
єднують навчання і роботу в екстремальних умовах під час постійних короткострокових і довгострокових виїздів на пожежі та інші надзвичайні ситуації впродовж всього періоду навчання в університеті. Автором показана можливість проведення таких досліджень на кафедрі практичної психології та педагогіки, тому що курсанти студенти 3 перших днів навчання в університеті працюють 3 дистанційними курсами, запропонованими викладачами кафедри практичної психології, інших кафедр Навчально-наукового інституту психології і соціального захисту та інших інститутів, можуть оцінити організацію їх використання, поки що, як додатковий навчальний матеріал, а також ДК, які пропонують, наприклад, громадський проект масових відкритих онлайн-курсів Прометеус (Prometheus) і компанія онлайн освіти Курсера (Coursera), побачити своє місце в удосконаленні університетських і в перспективі своїх майбутніх власних ДК як фахівців в галузі психології, провести дослідження на рівні курсової, бакалаврської та магістерської робіт. Описано також досвід проведення подібних досліджень, які стосуються організації дистанційного навчання і прикладної лінгвістики студентами Львівської політехніки під керівництвом професора Б. Шуневича у 2005-2007 pp.

Ключові слова: психолого-педагогічні особливості, дистанційне і комбіноване навчання, дистанційний курс.

\section{Prospect Trend of Compiling and Defending Master} Degrees Papers on Psychology

In the article the present trends of cadets and students researches in the form of course as well as bachelor's and master's degree papers at the Department of Practical Psychology and Pedagogics of Lviv State University of Life Safety (LSUofLS) are analyzed, the necessity, state and prospects of a new trend of compiling and defending masters' papers on the basis of researches on psychological and pedagogical peculiarities of compiling distance courses (DC), organization of distance and blended learning at Ukrainian higher schools taking into the account home experience in this sphere and especially cadets of LSUofLS who often combine their studying and working in extremal conditions during constant short term and long term departures because of fires and other emergency situations for the whole period of their studying at the University. The author represents the possibility of implementing such research at the Department of Practical Psychology and Pedagogics because the cadets and students use distance courses proposed by lecturers of the Department of Practical Psychology, 
other departments of the Educational and Scientific Institute of Psychology and Social Protection as well as other institutes for the whole period of studying at the University. They are also able to evaluate the organization of the DC usage first of all as additional educational materials as well as DC proposed, for example, by a public project of massive open online courses Prometheus and an online education company Coursera, to see their place in improving the University and the near future their own DC as specialists in the sphere of psychology, to conduct their researches on the level of course, bachelor's and master's degree papers. There is also described an experience of providing such investigations concerning distance learning organization and applied linguistics by the students of Lviv Polytechnic University under the guidance of professor B. Shunevych in 2005-2007.

Key words: psychological and pedagogical peculiarities, distance and blended learning, distance course.

$$
\begin{array}{r}
\text { Рецензент - доктор педагогічних наук, } \\
\text { професор Г. П. Васянович }
\end{array}
$$

